\title{
Analysis of Program Implementation Education of Consumer Protection in Improving Consumer Empowerment Index
}

\author{
Agus Satory*, Lasmin Alfies Sihombing, Yeni Nuraeni, Mustaqim Mustaqim \\ Legal Studies Program, Postgraduate Program \\ Pakuan University \\ Bogor, Indonesia \\ *agussatory@unpak.ac.id
}

\begin{abstract}
There are two main factors that have triggered a low level of Consumer Empowerment Index (IKK) in Indonesia, namely the lack of public knowledge about regulations and institutions related to consumer protection, and complaints that are not common among consumers. Improved education can take advantage of the involvement of many Consumer Protections NGOs in various regions by prioritizing strengthening the consumer empowerment in eight sectors, particularly clean water, energy, health, medicine and food, housing and property, transportation, financial services and e-commerce. This study aims to analyze the implementation of consumer protection education programs in improving the IKK. The method of approach taken in this research is a normative juridical approach and is supported by empirical research. The results of the study show that on average consumers in Indonesia are still helpless with an IKK score of 40.41 ("capable" level) in 2018. This means that Indonesian consumers are only limited to being able to use their rights and obligations as consumers to determine the best choice and to use domestic products. IKK is an index that measures the level of consumer empowerment in Indonesia. The higher the value of the IKK shows that consumers in Indonesia are increasingly empowered.
\end{abstract}

Keywords: consumer protection education, consumer empowerment index

\section{INTRODUCTION}

The rapid national development has resulted in the diversification of products and / or services that can be consumed. Such conditions, on the one hand, are very beneficial for the interests of consumers because the desired needs can be met and increasingly wide-open freedom to choose various types of quality goods and / or services in accordance with their abilities. On the other hand, these conditions and phenomena can cause the position of business actors and consumers to become unbalanced. Where consumers are only used as objects of business activity of business actors to reap maximum profits through advertising tips, promotions, ways of selling, and the application of standard agreements that harm consumers.
The low awareness and knowledge of the consumer community, it is not impossible to be used as a land for business actors in transactions that do not have good intentions in running a business, which is principally seeking maximum profit by utilizing as efficiently as possible the available resources [1]. An increasingly complex economic system has an impact on changes in legal construction in the relationship between producers and consumers. Changes in legitimate construction begin with a change in the paradigm of the relationship between consumers and producers. The relationship that was originally built on the principle of caveat emptor (which emphasizes that consumers must be careful in making transactions with producers), is transformed into the principle of caveat venditor (which emphasizes the awareness of producers to protect consumers) [2].

Based on these conditions the necessary effort to empower consumers through the establishment of laws that protect consumers' interests in integrated and comprehensive and can be applied effectively in the community. Regulatory instruments are not intended to shut down the business of business, but rather to promote a healthy business climate and the birth of the company in the face of tough competition through service and supply of goods and / or service quality. Attitude alignment to consumers was also intended as a form of high concern to consumers (wise consumerism) [3].

The main factor that becomes the weakness of consumers is the level of consumer awareness of their rights is still low, and the regulations are stagnant inadequate to equalize the bargaining position of consumers with business actors and guarantee consumer rights [4]. Weak bargaining position in terms of economic capacity and legal efforts of consumers in defending their rights, resulting in consumers being the object of business activity to reap maximum profits by business actors through advertising tips, promotions, ways of selling, and the application of standard agreements that harm consumers [5]. In fact, these consumer weaknesses are increasingly felt amid increasing marketing technology [6]. 
At a macro level, the powerlessness of consumers in dealing with business people can be seen from various sides, namely: first, from the consumer side against itself, for example, the powerlessness in the economic field, education level, and bargaining power as internal factors; second, in terms of business actors and the legal conditions that protect them as external factors; and third, the role of the state or government in consumer protection that has not been fully in favor of consumers [7].

The results of the mapping of the Indonesian Consumer Empowerment Index (IKK), conducted by the Ministry of Trade in 2016 showed that the value of the Indonesian IKK was 30.86 ("understand" level) of the maximum value of 100 , meaning generally shows consumers tend not to know the laws and consumer protection agencies, and do not file complaints when they feel disadvantaged [8]. While the target set by the National Consumer Protection Agency (BPKN) could increase to a level of 39 percent in 2018, it was exceeded until it reached a score of 40.41 ("able" level). It is expected that in the next five years IKK in Indonesia will increase from the level of "able" to "critical," that is, consumers can play an active role in fighting for rights and carrying out their obligations and prioritizing domestic products. To reach that target, The Ministry of Trade and BPKN prioritizes strengthening the consumer empowerment in eight sectors, namely clean water, energy, health, medicine and food, housing and property, transportation, financing or financial services and e-commerce.

However, based on the results of a survey conducted by Puska Dagri of nearly 5,000 consumers throughout Indonesia, on average more than $80 \%$ of them do not know and do not participate in the socialization activities "Smart Consumers." Thus, the government is deemed necessary to use other means in an effort to empower consumers. One of them is targeting the empowerment program to certain consumer groups, for example, the conscious promotion of SNI through the Standardization Society (MASTAN). This consumer group functions to educate, and advocate related to consumer protection to its members [9].

Based on the description above, then the aim of this study is to examine how the implementation of consumer protection education programs, in increasing the consumer empowerment index in Indonesia and what efforts have been made by the government and institutions related to consumer protection in empowering consumers.

\section{MethoDS}

The method of the approach taken in this research is a normative juridical approach and is supported by empirical research. This research is descriptive-analytic, that is research by explaining and describing in a clear, systematic, real, and precise way an alternative model of consumer service disputes in the financial service's sector in Indonesia, related to the theory and practice of its implementation. As for the processing of the data, both primary and secondary data are carried out qualitatively, meaning that they are translated with words, so they are sentences that can be understood and can be justified. However, it does not rule out the possibility to use quantitative data processing, which is to present with numbers and tables if necessary.

\section{RESULTS AND DISCUSSION}

The increasingly complex economic system has an impact on changes in legal construction in the relationship between producers and consumers. The change in legal construction begins with a paradigm shift in the relationship between consumers and producers. The relationship that was originally built on the principle of caveat emptor (which emphasizes consumers must be careful in making transactions with producers), changed to the principle of caveat venditor (which emphasizes the awareness of producers to protect consumers) [10].

Imbalance of position between producers and consumers really needs to be compensated with a variety of efforts, both through the consumer protection movement, institutional and legal devices, as well as various other efforts so that consumers can consume products or services they want more safely. Protection for a large number of consumers in a production business like this is a must, because advanced economic and industrial developments carry other negative implications [11].

To protect consumers from imbalances, the government is obliged to think of various policies aimed at protecting the public as consumers. In Indonesia, the significance of regulating consumer rights through legislation is part of implementation of a welfare state, because the 1945 Constitution of the Republic of Indonesia in addition to being a political constitution is also referred to as an economic constitution, namely a constitution that contains the idea of a welfare state, which grew due to the influence of socialism since the 19th century. Indonesia through UUPK establishes nine consumer rights, as a translation of the articles which are characterized by the welfare state, its Pasal 27 ayat (2) and Pasal 33 UUD Negara Republik Indonesia Tahun 1945 [12].

Consumer rights as stated in Articles 4 of the UUPK are inherent rights for anyone who is a consumer, as well as a subject. Thus it is a freedom for consumers to be able to present these rights in a container or group. The principle of freedom is an important characteristic for both consumer organizations and consumer groups. This freedom is not an absolute freedom but is relative. That is, these freedoms will still be inherent and can be used by consumers or consumer groups as long as those rights are used to defend their rights as consumers.

To protect consumers from imbalances, the government is obliged to think of various policies aimed at protecting the public as consumers. In Indonesia, the significance of regulating consumer rights through legislation is part of implementation of a welfare state, because the 1945 Constitution of the Republic of Indonesia in addition to being a political constitution is also referred to as an economic constitution, namely a constitution that contains the idea of a welfare state, which grew due to the influence of socialism since the 19th century. Indonesia through UUPK establishes nine consumer rights, as a translation of the articles which are 
- Consumer group education, including by including the consumer protection curriculum in formal education, from elementary, secondary to tertiary levels, and nonformal education through various courses and counseling;

- Seminars, panel discussions, symposiums or the like by conducting a scientific study of consumer protection, both legal and empirical in nature;

- Dissemination of information or actual news on transactions between business actors and consumers involving control and guidance and supervision from the government;

- The formation of associations or associations of consumers who have the same interests, especially in the public sector such as electricity and drinking water;

- Research and development of consumer protection, both concerning local and foreign products.

While practically, consumer empowerment can be pursued through: law is expected to be effective in protecting 250 million Indonesians, who are consumers [13].

At the implementation level, the UUPK still experiences various obstacles, including: (1) the implementation of the UUPK, and its implementing regulations have not yet run simultaneously and comprehensively, as if the interdepartmental are operating independently, there is no integration; (2) sector all regulations on consumer protection sometimes conflict with one another, not synergize with each other, and once in a while conflicting; and (3) there are still many law enforcement officers who do not understand the substance of UUPK, even the response of consumers and producers to UUPK is stillness low [14].

Powerlessness does not refer to the absence of power at all. Chambers states, that the situation of helplessness can be overcome [15]: “... enabling and empowering the poor through 'reversals in management' of dominant paradigms of development, which involves shifting power and initiatives downwards and outwards." In reality, those who seem to have little power are in point of fact able to survive, overthrow and sometimes transform their living conditions. This power actually exists, but it still needs to be revealed and developed.

Consumer empowerment is an effort aimed at providing protection to consumers through recognition and fulfillment of their rights that are legally adequate. The scope of this empowerment, covers broad policies, namely: Making laws and regulations is fair, balanced, and recognize consumer rights; Attitudes and decision-making policies are responsive to consumer problems; Legal arrangements that govern various obligations, and responsibilities must be carried out by business actors for goods and services starting from the production process up to the hands of consumers; Condition business actors to be ethical and morally responsible for the safety, security and comfort of goods or services are produced and marketed [16].

Theoretically, consumer empowerment can be pursued through [17]:
- Harmonization of legislation in the field of consumer protection in order to support educated and professional implementers in the field;

- Consumer empowerment agencies such as the NonGovernmental Consumer Protection Agency (LPKSM), the Consumer Dispute Resolution Agency (BPSK), and the National Consumer Protection Agency (BPKN) must make efforts to provide legal assistance and advocacy quickly and for free.

The most important effort is how to empower consumers as potential parties to suffer losses in dealing with business actors, so that in the future their rights are not violated by business actors. In fact, the consumer is indeed a party that must be protected, because after all as a party that is in a low bargaining position or weaker when compared with business actors. They deserve to get protection.

Analysis of the Consumer Empowerment Index (IKK) is carried out by the Directorate of Consumer Empowerment, The Ministry of Trade in collaboration with the Bogor Agricultural Institute (IPB) is motivated by the fact that with the increasing variety of goods and services available in the market, consumers should be empowered so they can protect themselves from harmful things. This study aims to analyze the demographics, social and economic aspects [18].

The level of consumer empowerment or IKK score is grouped into 5, namely:

1) Conscious: recognize basic rights and obligations as consumers (index score 0.0 - 20.0);

2) Understanding: understanding the rights and obligations of consumers to protect themselves (index score 20.1 - 40.0); index of consumer empowerment and its dimensions by region, 
3) Ability: able to use the rights and obligations of consumers to determine the best choices, including using domestic products for themselves and their environment (index score 40.1 - 60.0);

4) Critical: playing an active role in fighting for rights and carrying out their obligations and prioritizing domestic products (index score 60.1 - 80.0);

5) Empowered: having high nationalism in interacting with the market and fighting for the interests of consumers (index score 80.1 - 100.0).

If analyzed based on demographic characteristics, the most powerful consumers are women, live in urban areas, have an age range of 25-54 years, have a higher-education equivalent, to a degree, or higher, and earn an average of above 10 million per month. Based on these results, it is expected that in the next five years the Consumer Empowerment Index in Indonesia will increase from the level of "able" to "critical," that is, consumers can play an active role in fighting for rights and carrying out their obligations and prioritizing domestic products.

BPKN considers that there are two main factors that have triggered the low IKK in Indonesia. The first factor is the lack of public knowledge about regulations and institutions related to consumer protection. The second factor is complaint's behavior that is not yet common among consumers. Among the seven indicators of consumer empowerment, the two things above have the lowest score. While five other indicators are consumer activity in information search, product selection, product preferences, buying behavior, and reporting tendencies. Education about the public regarding consumer rights is still lacking. Increased education can take advantage of the involvement of many Consumer Protections NGOs in various regions. Therefore, BPKN plans to increase the capacity of these consumer protections NGO activists.

The process is reflected in the implementation of various consumer empowerment programs that have been carried out by the Indonesian Ministry of Trade, YLKI, LPKSM, BPSK, BPOM, the District / City Industry, Trade and Cooperatives Office, and the private sector. One of the consumer empowerment programs undertaken is consumer education, including the frequency of consumer education, the type of media used, and consumer education materials provided. The resulting output of consumer empowerment is consumer empowerment, which includes three dimensions, namely consumer skills with sub-dimensions of basic skills, understanding of labels and label reading skills. The second dimension is the experience of unjust practices and fulfillment of consumer rights with the sub dimensions of experience of unfair practice of business actors and the fulfillment of consumer rights. The third dimension is the firmness of consumers with sub dimensions of product comparison, understanding of the law and the Consumer Protection Agency, the tendency of consumers to talk, and complaints and compensation.

The Government through the Ministry of Trade of the Republic of Indonesia and related agencies, as well as consumer protection institutions such as YLKI, BPSK,
LPKSM, and BPKN have made various efforts to empower consumers, including:

1) Consumer protection in Indonesia is carried out based on UUPK. The UUPK is formulated concerning the state development philosophy. Wherein domestic development is inherent in efforts aimed at providing protection to the people of Indonesia.

2) Institutional Development. The existence of the Directorate of Consumer Empowerment at the Ministry of Trade of the Republic of Indonesia with the prime task is to carry out the formulation and implementation of policies, preparation of guidelines, norms, standards, procedures and criteria as well as providing technical guidance and evaluation of policy implementation in the field of consumer empowerment. The consumer empowerment, institution which is the extension of the Directorate of Consumer Empowerment at the Indonesian Ministry of Trade, is:

- National Consumer Protection Agency (BPKN) which was formed as an effort to respond to the dynamics and needs of consumer protection that are growing rapidly in the community;

- Consumer Dispute Settlement Agency (BPSK), which is a consumer justice institution domiciled in each district or city throughout Indonesia, except for Jakarta, which is located in DKI Jakarta Province, with the principal task of resolving consumer disputes outside the general court institutions; and

- Non-Governmental Consumer Protection Institution (LPKSM), which aims to create legal certainty to protect consumers / communities that use goods and services; and the Indonesian Consumer Institution Foundation (YLKI) which aims to increase consumers' critical awareness about their rights and responsibilities, so that they can protect themselves and their environment.

3) Consumer Education. Consumer Education activities are carried out through Integrated Consumer Clinics (KKT), Motivators and Consumer Community Movements, Development of Consumer Information Services in Universities, intelligent Shopping Education, Consumer Complaints online (Siswas PK, Hotline-Call Centers), as well as socialization through electronic media and print media. The launch of the "Consumer clever movement with the slogan "let's be smartness consumers" with the mouse deer mascot named "Si Koncer" as an effort / invitation to consumers to be critical, smart and careful in consuming and utilizing goods and / or services. Dissemination of consumer protection policies on consumers and business actors in various regions, including one of which is the dissemination of business actors about risky substances, as an effort to minimize the use of unsafe materials that are not in accordance with their designation.

4) Strengthening consumer protection, through various regulations, including requiring producers and importers to put labels in Indonesian language on products traded in 
Indonesian territory. This aims to ensure consumers get correct, clear and honest information about condition and guarantee of the item to be used.

5) Varied consumer protection institutions, open complaints for consumer problems, including by BPOM (Food and Drug Supervisory Agency) by opening a Consumer Complaint Service Unit (ULPK) to accommodate complaints and provide information to the public relating to the safety, usefulness and quality and legality aspects of many products, including food and beverages. The ULPK activity consists of oral and written service to complaints, complaints and information that enter directly, by telephone, SMS, facsimile, e-mail or post / mail; guidance on consumer complaint's services such as counseling, dissemination of information and training as well as recording and evaluating data both at the center and in the regions. Various counseling are also carried out to the community, including high-school students, teachers, and parents [19].

Therefore, there are still some efforts to empower consumers comprehensively through three parties, namely consumers, business actors, and the state or government or third parties. That is, in the empowerment of consumers, in addition to the consumers themselves, it is also the responsibility of producers (business people) and the state or government or third parties, even though this research still focuses on empowerment from the consumer side first.

\section{CONCLUSIONS}

Empowerment shows involvement empowered parties; awakened mind, reason and endeavor; there are retrieval decisions and there are concrete actions by, and for oneself empowered. Through empowerment, efforts mean consumers become empowered, have the ability to show themselves and their existence as consumer means also consumers have awareness of their rights and obligations as consumers in the relationship between producers and consumers.

IKK Indonesia, which has risen from "understanding" to be "able" to have a positive impact, not only for consumers. Improving the level of understanding of consumers of their rights will lead to increased quality and product competitiveness. The reason is, consumers who are getting smarter about their rights will not accept products or services carelessly. The rise in IKK also shows the ability of the government in maintaining people's purchasing power. Some of the things that he considered making IKK able to increase were the existence of orderly measures for the scales in the market that were indeed being intensified by the Ministry of Trade. The current rules are good enough to be capable of pursue the IKK target to be 45 in 2019, from 40.41 in 2018. It's just that it needs to be stricter implementation of rules so that each party meets these rules, ranging from orderly rules to stock trading.

Efforts to empower consumers related to the formulation of policies, standards, norms, criteria and procedures, technical guidance, and evaluation of implementation in the fields of cooperation, information and publication on consumer empowerment, analysis of the implementation of consumer empowerment, guidance of consumers and business actors, service complaints and institutional facilitation of consumer protection. The outcome resulting from consumer empowerment is a consumer subjective well-being which includes dimensions of fulfillment of needs, consumption, consumer education, consumer rights, and consumer protection.

The implication of this research is if the consumer protection education program can be implemented well by the stakeholders, then it will correlate with increasing consumer empowerment or IKK score from the level of "able" (able to use the rights and obligations of consumers to determine the best choice, including using domestic products for themselves and their environment) to the level of "critical" (active role in fighting for rights and carrying out their obligations as well prioritizing domestic products), even to the level of "empowered" (having high nationalism in interacting with the market and fighting for the interests of consumers) of Indonesia's potential population of 269 million by 2019 .

\section{ACKNOWLEDGMENT}

I would like to thank the Rector of Pakuan University and the Director of the Pakuan University Postgraduate Program for funding and providing the opportunity to conduct this research.

\section{REFERENCES}

[1] D.W. Oughton, J. Lowry. Textbook on Consumer Law. Blackstore Press Ltd, London; 1997.

[2] A. Satory. "Alternative Model of Consumer Dispute Settlement In The Financial Services Sector in Indonesia". Journal Communications on Stochastic Analysis (COSA) Volume 13, Number 6, Juni 2019. Editorin-Chief HUI-HSIUNG KUO. Serials Publications (P) Ltd., ISSN: 09739599. (p. 73-82); 2019.

[3] A. Satory. "Authority of The Consumer Dispute Settlement Body in Education of Consumer Protection in Financial Services Sector". Proceeding in The $2^{\text {nd }}$ Asian Education Symposium 2017, Publisher SCITEPRESS (Scientific and Technology Publications Lda) - Volume 1: AES, ISBN 978-989-758-331-5, pages 334-337. DOI: 10.5220/0007303803340337; 2017.

[4] A.H. Barkatullah. Legal Protection for Consumers in Cross-Country Ecommerce Transactions in Indonesia. FH UII Press, Yogyakarta; 2009.

[5] A. Sutedi. Product Responsibility in Consumer Protection Law. Ghalia Indonesia, Bogor; 2008

[6] N.H.T. Siahaan. Consumer Law: Consumer Protection and Product Responsibility. Panta Rei, Jakarta; 2005.

[7] P. Suraji. Empowerment and Legal Protection for Consumers in the Context of Protecting the Interests of Underprivileged Consumers. Journal of Yustisia Vol.2 No.3 September - December 2013, Faculty of Law Sebelas Maret University Surakarta; 2013.

[8] Unknown, [Online] Available at: https://www.mendag-konsumencerdas-pacu-peningkatan-daya-saing-produk-nasional, accessed August 22, 2019.

[9] Final Report of the Ministry of Trade. Consumer Group Analysis (Consumer Group) In Efforts To Increase Consumer Empowerment; 2016. 
[15] R. Chambers. Rural Development: Putting the Last First. Longman, New York; 1983

[16] A. Zazili, Hartono. The Consumer Empowerment Model Against the Threat of Hazardous Food Products Contaminated with Toxic Hazardous Materials in Lampung Province. IUS QUIA IUSTUM Law Journal No. 3 Vol. July 23, 2016: 391 - 414; 2016.

[17] I. Rini. Empowering Consumers in Facing the Challenges of Global Competition. Journal of Perspective, Volume VI Number 3, July 2001.

[18] M. Simanjuntak. Level of Empowerment and Consumer Empowerment Strategies. Dissertation at Bogor Agricultural Institute Graduate School; 2014.

[19] Unknown, [Online] Available at: http://www.ulpk.pom.go.id. accessed August 21, 2019 Implementation in Indonesia. Padjadjaran Journal of Legal Sciences, Faculty of Law, Padjadjaran University Bandung, Vol. II No. August 2, 2015, [ISSN 2460-1543] [e-ISSN 2442-9325]; 2015.

[14] M.A. Mansyur. Contemporary Responsive Consumer Protection: Ideas for Creating Dignified Consumers and Responsible Producers. Unissula Press, Semarang; 2007. 